\title{
Spectrum of unnatural deaths: autopsies conducted at A. J. Institute of medical sciences \& research centre, Mangalore
}

\author{
M. Deepak ${ }^{1}$, Bharath Shetty ${ }^{2 *}$, Francis N.P. Monteiro ${ }^{3}$, Karen Prajwal Castelino ${ }^{4}$, Arun Pinchu Xavier ${ }^{5}$, Tanush \\ Shetty ${ }^{6}$
}

\begin{abstract}
${ }^{1-2,4-6}$ Assistant Professor, Professor and HOD, ${ }^{1-6}$ Department of Forensic Medicine \& Toxicology, ${ }^{1}$ Shimoga Institute of Medical Sciences, Shivamogga, ${ }^{2}$ KVG Medical College, Kurunjibag, Sullia, ${ }^{3,6}$ A.J. Institute of Medical Sciences \& Research Centre, Mangalore, ${ }^{4}$ Father Muller Medical College, Mangalore, ${ }^{5}$ Mookambika Institute of Medical Sciences, Kulasekharam, Tamil Nadu, Karnataka, India
\end{abstract}

*Corresponding Author: Bharath Shetty

Email: doctorbharathshetty@ hotmail.com

\begin{abstract}
Introduction: The incidence of unnatural deaths is found to be persistently increasing. Pattern of unnatural deaths is a reflection of the prevailing social set up and mental health status of the population.

Aim: This retrospective and prospective study was undertaken to analyze the various aspects related to unnatural deaths autopsied at A. J. Institute of Medical Sciences \& Research Centre, Mangalore which is tertiary health care teaching hospital catering the healthcare needs of rural population of coastal Karnataka and Northern districts of Kerala.

Materials and Methods: Materials for the present retrospective and prospective study consists of unnatural deaths autopsied at Department of Forensic Medicine \& Toxicology, A. J. Institute of Medical Sciences \& Research Centre, Mangalore, Karnataka, during the period from January 2005 to September 2013. All the relevant data were studied from police inquest reports, postmortem reports, chemical analysis report, histopathology report, hospital record findings, and information obtained from relatives and friends. Due permission was taken from Institutional Ethics Committee of A.J. institute of Medical Sciences \& Research Centre, Mangalore for the conduct of the study. Results: Among 797 unnatural deaths, 643 were males and 154 were females. Five hundred and fourteen cases of unnatural deaths were in the age group of 20 to 49 years with a peak incidence of $30 \%$ in the age group of 20 to 29 years. Sixty three percent of unnatural deaths were secondary to Road traffic accident followed by those resulted from poisoning (9\%). Males outnumbered females in all types of unnatural deaths except in case of burns. Majority of unnatural deaths were due to accidents (83\%) followed by Suicide (12\%), homicide $(3 \%)$ etc.

Twenty percent of suicide victims had underlying Psychiatric illness. Violence was the preferred means of mechanical injuries (77\%) followed by burning (19\%) and drowning (1\%).

Conclusion: Males are the predominant victims of unnatural deaths probably due to social interaction and outdoor activities. Younger age group is the common victim of unnatural deaths. The most significant cause of death was trauma in road traffic accidents. A significant number of deaths resulting from RTAs need proper reforms in terms of traffic regulation.
\end{abstract}

Keywords: Accidental, Autopsy, Cause of death, Manner of death, Unnatural deaths.

\section{Introduction}

Death in inevitable-whether we like it or not. Although it is inescapable, cannot be gainsaid yet not accepted with ease. Death become more troublesome when it is unnatural, i.e. against the order of nature or prematurely caused by injury, violence or poison. The incidence of unnatural deaths is found to be persistently increasing. Pattern of unnatural deaths is a reflection of the prevailing social set up and mental health status of the population. In an attempt to understand the magnitude and pattern of unnatural deaths, the study of unnatural deaths by the autopsies conducted at A.J. Institute of Medical Sciences \& Research Centre, Mangalore during the period from January 2005 to September 2013 was carried out. Retrospective and prospective study consisting of medico-legal autopsies conducted at Department of Forensic Medicine \& Toxicology, A. J. Institute of Medical Sciences \& Research Centre, Mangalore during the period from January 2005 to September 2013 with an aim to describe epidemiological characteristics and to analyze the magnitude and pattern of unnatural deaths in this part of the country so that possible preventive measures can be suggested and taken up accordingly.

\section{Materials and Methods}

Materials for the present study consists of unnatural deaths autopsied at Department of Forensic Medicine \& Toxicology, A. J. Institute of Medical Sciences \& Research Centre, Mangalore, Karnataka, during the period from January 2005 to September 2013. All the relevant data were studied from police inquest reports, postmortem reports, chemical analysis report, histopathology report, hospital record findings, and information obtained from relatives and friends. Due permission was taken from Institutional Ethics Committee of A.J. institute of Medical Sciences \& Research Centre, Mangalore for the conduct of the study.

The information pertaining to age, sex, incident as per police inquest, organ affected leading to death, circumstances leading to death, timing of occurrence, in case of road traffic accidents- type of vehicle collided with the victim in case of pedestrian, type of occupant, etc.; in case of poisoning- type of poison, place of occurrence, timing of consumption, reasons in case of suicide; in case of violence- type of offending weapon; in case of hanging- 
place of occurrence, timing of hanging, reasons in case of suicide; in case of burns- place of occurrence, timing, reasons in case of suicide, duration of survival, body surface area burnt; etc. recorded in a pre structured proforma and analyzed.

All unnatural deaths autopsied at Department of Forensic Medicine and Toxicology, A.J. Institute of Medical Sciences \& Research Centre, Mangalore, Karnataka were included in this study except sudden death cases which later revealed to be death due to natural causes and autopsies on decomposed bodies wherein definite opinion could not be ascertained.

Base line data will be represented using various forms of diagrams and graphs. Statistical analysis was carried out using IBM SPSS Statistics (IBM Inc., version 17 for Windows) software package.

\section{Results}

During the study period from January 2005 to September 2013, 865 medico-legal autopsies were conducted at A. J. Institute of Medical Sciences \& Research Centre, Mangalore, Karnataka. Out of which 797 were of unnatural deaths and 68 were those belonging to natural death and of undetermined causes.

Among 797 unnatural deaths, 643 were males and 154 were females. Out of total 797 cases of unnatural deaths, most of the deaths $(78.17 \%)$ belong to those from Hindu religion followed by Muslims (11.54\%) and Christians $(9.28 \%)$.

Five hundred and fourteen cases of unnatural deaths were in the age group of 20 to 49 years with a peak incidence of $30 \%$ in the age group of 20 to 29 years as shown in Table 1 . The youngest victim was 3 months old and the oldest was 85 years old.

Table 1: Age wise distribution of unnatural deaths

\begin{tabular}{|l|c|c|c|}
\hline Age distribution & Males & Females & No. $(\%)$ \\
\hline $00-09$ & 13 & 16 & $029(03.64)$ \\
\hline $10-19$ & 33 & 21 & $054(06.78)$ \\
\hline $20-29$ & 198 & 39 & $237(29.74)$ \\
\hline $30-39$ & 134 & 17 & $151(18.95)$ \\
\hline $40-49$ & 106 & 20 & $126(15.81)$ \\
\hline $50-59$ & 81 & 16 & $097(12.17)$ \\
\hline$>60$ & 78 & 25 & $103(12.92)$ \\
\hline Total & $\mathbf{6 4 3}$ & $\mathbf{1 5 4}$ & $\mathbf{7 9 7}$ \\
\hline
\end{tabular}

Two hundred and fifty one cases were reported between the months of March and May with a peak incidence of 85 cases in the month of March as shown in Table 2.

Table 2: Distribution of unnatural deaths in relation to year and month

\begin{tabular}{|l|l|l|l|l|l|l|l|l|l|l|}
\hline Month & $\mathbf{2 0 0 5}$ & $\mathbf{2 0 0 6}$ & $\mathbf{2 0 0 7}$ & $\mathbf{2 0 0 8}$ & $\mathbf{2 0 0 9}$ & $\mathbf{2 0 1 0}$ & $\mathbf{2 0 1 1}$ & $\mathbf{2 0 1 2}$ & $\mathbf{2 0 1 3}$ & Total No. (\%) \\
\hline Jan & 2 & 7 & 6 & 4 & 7 & 10 & 5 & 11 & 11 & $63(07.90)$ \\
\hline Feb & 3 & 5 & 5 & 4 & 4 & 9 & 7 & 13 & 11 & $61(07.65)$ \\
\hline Mar & 4 & 7 & 10 & 3 & 7 & 8 & 9 & 20 & 17 & $85(10.66)$ \\
\hline Apr & 10 & 8 & 13 & 9 & 4 & 9 & 10 & 6 & 14 & $83(10.41)$ \\
\hline May & 6 & 8 & 3 & 9 & 8 & 19 & 8 & 11 & 11 & $83(10.41)$ \\
\hline June & 6 & 4 & 3 & 8 & 4 & 5 & 12 & 8 & 9 & $59(07.40)$ \\
\hline July & 3 & 4 & 7 & 2 & 12 & 7 & 9 & 7 & 11 & $62(07.78)$ \\
\hline Aug & 6 & 5 & 5 & 4 & 6 & 10 & 8 & 6 & 11 & $61(07.65)$ \\
\hline Sep & 2 & 7 & 0 & 6 & 7 & 9 & 11 & 12 & 10 & $64(08.03)$ \\
\hline Oct & 8 & 6 & 2 & 6 & 6 & 6 & 15 & 17 & - & $66(08.28)$ \\
\hline Nov & 8 & 1 & 5 & 11 & 2 & 7 & 10 & 13 & - & $57(07.15)$ \\
\hline Dec & 5 & 8 & 7 & 4 & 8 & 6 & 5 & 10 & - & $53(06.64)$ \\
\hline Total & $\mathbf{6 3}$ & $\mathbf{7 0}$ & $\mathbf{6 6}$ & $\mathbf{7 0}$ & $\mathbf{7 5}$ & $\mathbf{1 0 5}$ & $\mathbf{1 0 9}$ & $\mathbf{1 3 4}$ & $\mathbf{1 0 5}$ & $\mathbf{7 9 7}$ \\
\hline
\end{tabular}

Sixty three percent of unnatural deaths were secondary to Road traffic accident followed by those resulted from poisoning $(9 \%)$ and those resulted from fall from height $(7 \%)$ as shown in Figure 1. Among the three miscellaneous type of unnatural death, two resulted from crush injury and one as a result of anaesthesia. Males outnumbered females in all types of unnatural deaths except in case of burns.

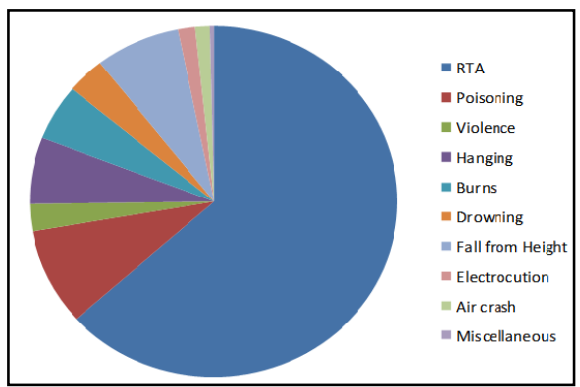

Fig. 1: Chart depicting distribution of different types of unnatural deaths 
According to the information furnished in the police inquest form, majority of unnatural death amongst 797 cases autopsied were due to accidents $(83 \%)$ followed by Suicide $(12 \%)$, homicide $(3 \%)$ etc. The detailed manner/Nature of individual unnatural deaths was elaborated in Table 3.

Table 3: Distribution of Nature/Manner of death amongst individual unnatural death

\begin{tabular}{|c|c|c|c|c|c|}
\hline & Accident & Suicide & Homicide & Sudden Unexplained death & Total \\
\hline & No. $(\%)$ & No. $(\%)$ & No. $(\%)$ & No. $(\%)$ & No. $(\%)$ \\
\hline RTA & $505(63.36)$ & $00(00.00)$ & $00(00.00)$ & $00(00.00)$ & $505(63.36)$ \\
\hline Drowning & $22(02.76)$ & $04(00.50)$ & $01(00.13)$ & $00(00.00)$ & 27 (03.39) \\
\hline Poisoning & $23(02.89)$ & $36(04.52)$ & $00(00.00)$ & $12(01.51)$ & $71(08.91)$ \\
\hline Hanging & $00(00.00)$ & $49(06.15)$ & $00(00.00)$ & $00(00.00)$ & $49(06.15)$ \\
\hline Violence & $00(00.00)$ & $00(00.00)$ & $20(02.51)$ & $00(00.00)$ & $20(02.51)$ \\
\hline Burns & $36(04.52)$ & $00(00.00)$ & $05(00.63)$ & $00(00.00)$ & $41(05.14)$ \\
\hline Electrocution & $12(01.51)$ & $00(00.00)$ & $00(00.00)$ & $00(00.00)$ & $12(01.51)$ \\
\hline Air crash & $10(01.25)$ & $00(00.00)$ & $00(00.00)$ & $00(00.00)$ & $10(01.25)$ \\
\hline Fall from height & $50(06.27)$ & $09(01.13)$ & $00(00.00)$ & $00(00.00)$ & $59(07.40)$ \\
\hline Miscellaneous & $03(00.38)$ & $00(00.00)$ & $00(00.00)$ & $00(00.00)$ & $03(00.38)$ \\
\hline Total & $661(82.94)$ & $98(12.30)$ & $26(03.26)$ & $12(01.51)$ & 797 \\
\hline
\end{tabular}

Amongst unnatural deaths studied in $41 \%$ of cases victim succumbed because of fatal brain injury followed by haemorrhage (15\%), Septcemia (14\%) and Asphyxia (11\%). Maximum number of RTA victims were occupants (Rider/Pillion) of two wheeler (44\% related to motor cycle and $1 \%$ related to bi-cycle) followed by pedestrians comprising of $23 \%$ of victims. In case of pedestrians maximum number got injured due to the collision of heavy motor vehicle $(40.35 \%)$ followed by two wheelers $(30 \%)$ as illustrated in Table 10.

In fifty eight percent of poisoning cases victims consumed poison indoor whereas in forty two percent of cases poison was consumed outside their dwelling. Forty seven percent of the poisoning victims consumed poison during the day and twenty seven percent of the poisoning victims consumed poison during night.

In majority of cases victims hanged themselves inside their dwelling $(82 \%)$.

Most of the burn victims (59\%) succumbed within 10days of sustaining burns as depicted in Table 15.

Fifty nine percent of victims sustained burns during day and twenty nine percent of victims sustained burns during night. Most of the victims (90\%) succumbing to burns sustained burn injuries involving more than forty percent of total body surface area burnt.

Twenty percent of suicide victims had underlying Psychiatric illness as illustrated in Table 4.

Table 4: Reasons for committing Suicide

\begin{tabular}{|l|c|}
\hline Reasons for suicide & No. (\%) \\
\hline Psychiatric illness & $53(54.08)$ \\
\hline Physical ailments & $10(10.20)$ \\
\hline Financial \& business loss & $10(10.20)$ \\
\hline Death of near \& dear ones & $06(06.12)$ \\
\hline
\end{tabular}

\begin{tabular}{|c|c|}
\hline Marital \& Love failure & $12(12.24)$ \\
\hline Exam failure & $03(03.06)$ \\
\hline Miscellaneous & $04(04.08)$ \\
\hline Total & $\mathbf{9 8}$ \\
\hline
\end{tabular}

Miscellaneous includes unemployment, scolding by sister and mistaking it to medicine.

Violence was the preferred means of mechanical injuries $(77 \%)$ followed by burning (19\%) and drowning (1\%) as depicted in Table No. 5. In sixty percent of violence related homicide preferred choice of weapon is sharp weapon $(60 \%)$.

Table 5: Means in case of Mechanical Injuries

\begin{tabular}{|c|c|}
\hline Means of Homicide & No. (\%) \\
\hline Violence & $20(76.92)$ \\
\hline Burns & $05(19.23)$ \\
\hline Drowning & $01(03.85)$ \\
\hline Total & $\mathbf{2 6}$ \\
\hline
\end{tabular}

\section{Discussion}

Unnatural death is one of the indicators of the level of social and mental health. Crime has never been free from any human society since their emergence on this earth. This study was undertaken to analyze the various aspects related to unnatural deaths autopsied at A. J. Institute of Medical Sciences \& Research Centre, Mangalore which is tertiary health care teaching hospital catering the healthcare needs of rural population of coastal Karnataka and Northern districts of Kerala.

Our study reflects gradual rise in medico-legal autopsies and unnatural deaths. A study reported from Pekanbaru, Indonesia showed a decreasing trend in unnatural deaths whereas the number of medicolegal autopsies increased over the years. ${ }^{1}$ Eighty one percent of unnatural death victims are of male gender, an observation 
which is similar to the studies done across the globe. ${ }^{1-6}$ The said finding has the following basis of logical explanation. Firstly, males go out for work, much more than their counterpart, exposing themselves or making themselves vulnerable various risks attributed with unnatural deaths. Secondly, men are mostly indulged with both socio-political rows (rivalry, revenging, killing, leadership crisis) and crimes acts (robbery, looting, drug abusing etc) than women. The lower instances of unnatural deaths in females are mainly attributed to custom, social values and preference of females to stay indoors.

There is unambiguous dominance of males in various types of unnatural deaths except in case of unnatural deaths resulting from burns in which females outnumber males by a large margin, similar to those reported from various parts of India, Pakistan and Iran. ${ }^{7-12}$ This high occurrence of burn deaths in females may be attributed to the fact that they are the main working hands for the domestic activities in kitchen and thus exposed to cooking on open, unguarded flame such as stove, chullha, cooking gas and other means. Females also presume that the burning is the easiest mode of ending life when there is hostility in their personal or marital life. This is in contrast to the literature reported from Imphal, Egypt, Spain and United States of America. ${ }^{13-16}$

Almost all age-groups were represented with the most being middle aged adult persons (20-29 years). In the studies reported from across India, Bangladesh, Indonesia, and Nigeria reported the similar trend. ${ }^{1}$ 13-16 This preponderance of younger age group could be attributed to the stressors one has to undergo at this age. This is the age at which the individual ventures into life defining moments of existence, such as employment, marriage and family responsibilities which makes the individual vulnerable to various hazards of life. Most of the unnatural death victims are from Hindu religion followed by Muslims and Christians, which is in accordance with the studies reported from other parts of India. ${ }^{17,18}$ This may be explained by the fact that the religion of most of the population of this locality is Hinduism.

Sixty three percent of unnatural deaths were secondary to road traffic accident, an observation corroborated by studies done across the nation and other countries. ${ }^{19-23}$ This trend is a universal issue, because of traffic overloading worldwide. In our context, the high incidence of RTA deaths could be due to pitiable enforcement of traffic rules and regulations, drunk driving, risk taking behavior of youngsters, and the intricate, twisting, winding nature of roads in the rural areas of coastal Karnataka. In city the high occurrence of RTA could be attributed to the better roads thereby increasing the risk of rash and negligent driving. The high proportion of young adults affected could be due to their high levels of activity, as they are the most economically active segment of the population. Most of the studies around the world agree to the finding that majority of fatal crash victims are that of male gender. ${ }^{24-28}$ Most of the RTA related deaths were in relation to two wheeler, either rider or pillion. Similar findings were observed in the studies reported from the same geographic location. ${ }^{29,30}$
Forty one percent of unnatural deaths wherein mortality is attributed to injury to brain alone, which is in concurrence with the study reported from northern part of India. ${ }^{31}$ This may be attributed to the fact that the bulk of deaths were those arising from RTA and head is most vulnerable part in the body in case of impact.

Accidental deaths constituted $83 \%$ of unnatural fatalities. A study conducted at Chandigarh also reported high incidence of accidental unnatural deaths followed by suicidal (13.9\%) and homicidal (6\%) deaths. ${ }^{32,33}$ Homicide is the predominant manner of death as per the study reported from Pekanbaru, Indonesia. ${ }^{1}$

During the study period we undertook autopsy on 10 victims in relation to heartbreaking and disturbing episode of Air India Express Boeing 737-800 flight IX-812 crash at the Mangalore International Airport on 22 May 2010 which lead death of total 158 people on board. Most of the bodies were charred beyond easy recognition, necessitating identification on the basis of DNA typing. ${ }^{34}$

Fifty eighty percent of poisoning victims consumed poison indoors. This high prevalence of indoor poison consumption is in concurrence with studies from others part of India. ${ }^{35-38}$ Seventy six percent of the poisoning victims consumed poison during day time. The rationale for preferring day time may be isolation of victims when the family members go out for work or kids to school, literate mass mostly in the day time are engaged in multifarious works resulting in great stress and strain and the stress will be in its peak during the day. ${ }^{37}$

Dominance of poison consumption during day time is in accordance with the trends observed in studies conducted worldwide. ${ }^{35-39}$ A study conducted in Nepal highlighted the poison consumption more prevalent during night time. ${ }^{40}$ Most of the victims succumbed to poisoning consumed agricultural pesticides. This is explained by the fact that in India, an agricultural country with a lack of strict regulation over the sale of these chemicals, such poisoning agents are easily accessible. The easy availability and cheaper price have made them a popular killer agent especially among the medium and low socioeconomic groups. Studies from other south Asian countries also show the main agents in poisonings to be agricultural chemicals. ${ }^{41-48}$ The gamut of poisoning deaths in developed countries contrasts remarkably with that of developing countries. Almost all of poisoning deaths in the United States are ascribed to drugs, mostly resulting from abuse of prescription and illegal drugs. A study from Palestine showed that the bulk of deliberate poisonings involved pharmaceutical agents. ${ }^{49,50}$ In majority of cases victims hanged themselves inside their dwellings. Similar findings were observed in the similar studies conducted elsewhere. ${ }^{51-53}$ Terminating life by hanging indoors reflects the fact that victims preferring isolation and privacy at their own dwelling.

Fifty nine percent of victims sustained burns during day time. This may be due to the fact that people are usually occupied in their work during daytime and therefore the burns are sustained in the course of their activities. ${ }^{54}$ 
The percentage of burn over $40 \%$ was observed in most of the cases $(90 \%)$. In a study from Egypt the overwhelming majority of the victims had more than $50 \%$ of total body surface area (TBSA) burns indicating the incompatibility with life even at a tertiary care center. Studies from Angola revealed $100 \%$ mortality over $40 \%$ TBSA. ${ }^{55}$ Similarly $80 \%$ mortality rate in burns over $40-50 \%$ TBSA has been reported from India, Albania and Saudi Arabia. ${ }^{57-58}$ Most of the burn victims succumbed within 10days of sustaining burns. In a Egyptian study $72 \%$ cases died within a few minutes to 24 hours, signifying that the burns are rapidly fatal. $^{14}$ Similarly Virendra et al. and; Vilasco and Bondurand emphasizes death from burns within a week. ${ }^{56,59}$ Early death, i.e., death within 48 hours of sustaining burns is mostly due to inhalation injury. ${ }^{60-63}$ Other significant causes of death resulting from burns are multiorgan failure, sepsis, pneumonia, ARDS, and pulmonary embolism.

Most of the suicide victims have a psychiatric illness, which is in concurrence with the studies across the globe. $^{64,65}$ Factors that increase the vulnerability to suicide include psychiatric disorders, drug misuse, psychological states, cultural, family and social situations, genetics, previous attempted suicide, the ready availability of a means to commit the act, a family history of suicide, or the presence of traumatic brain injury. ${ }^{66-68}$ Mental disorders are often present at the time of suicide with estimates ranging from $27 \%$ to more than $90 \%{ }^{67,69}$ Half of all people who die by suicide may have major depressive disorder; having this or one of the other mood disorders such as bipolar disorder increases the risk of suicide 20 -fold. ${ }^{69}$ Other conditions implicated include schizophrenia (14\%), personality disorders $(14 \%)$, bipolar disorder, and posttraumatic stress disorder. ${ }^{67,69,70}$ About 5\% of people with schizophrenia die of suicide. ${ }^{70}$ Thought of suicide is connected with the unbearable psychosomatic anguish resulting in a constriction of thinking that leaves the individual to see only two ways out, death or the continuance of unbearable and inevitable distress. ${ }^{72}$

In majority of cases, preferred method of killing used by the miscreants was by inflicting mechanical injury, which is in accordance with the studies reported from Surat and Bangalore. ${ }^{73-75}$ In sixty percent of the mechanical injury linked homicide preferred choice of weapon was sharp weapon. The increasing use of sharp cutting weapons by the people of this region could well be explained by the fact that these weapons are more dangerous than blunt weapons and are easily available due to agricultural background and at the same time non availability of firearms. In study conducted at District Government Hospital, Mangalore, Karnataka $49 \%$ of the cases, the victims had sustained sharp force injuries while in $35 \%$ blunt force injuries were present. ${ }^{76}$ A study reported from India, North America, Britain, Malaysia, and Ireland observed sharp weapons as dominant method used in homicide. ${ }^{77-81}$ Study conducted at Government Medical College, Jagdalpur, Chhattisgarh revealed blunt force as the most common method of homicide, which is in concurrence with the research conducted in central Delhi and in the region of Honshu island of Japan. ${ }^{82-84}$ In the United States, firearms are used in most of the homicides, over quarter of all assaults, and almost half of all suicides. ${ }^{85}$ This trend of dominance of firearm in homicide related incidents observed in other developed and developing countries alike. ${ }^{86-91}$

\section{Conclusion}

The law and order situation in a particular area of jurisdiction that is the basic reason to plan such studies for situational analysis of unnatural deaths in the region of study for comparison to the national \& global statistics in order to find out the possible remedies for minimizing the incidence of unnatural deaths. Gender predominance, rampant age group, causes and manners of unnatural deaths in our study are more or less similar to the pattern found in most of the national studies. The study set the goal of improving the situation by planning new reforms in terms of traffic regulations, improving literacy rate \& socioeconomic resolution

\section{Source of Funding: None.}

\section{Conflict of Interest: None.}

\section{References}

1. Dedi Afandi. Profile of medicolegal autopsies in Pekanbaru, Indonesia 2007-2011. Malaysian J Pathol 2012; 34(2): 123-6.

2. Islam MM, Khan AM. Gender Disparity in Autopsy Findings: How Much is It?. Faridpur Med. Coll. J. 2012; 7(1): 23-5.

3. Larsen ST, Lynnerup N. Medico-legal autopsies in Denmark. Dan Med Bull 2011;58(3):A4247.

4. Tiemensma M, Burger EH. Sudden and unexpected deaths in an adult population, Cape Town, South Africa, 2001-2005. S Afr Med J 2012;102:90-4.

5. Mandong BB, Manasseh AN, Ugwu BT. Medicolegal autopsies in North Central Nigeria. East Afr Med J 2006;83:626-30.

6. Khan BH, Hossain MM. Study on unnatural death patterns in Dhaka City. Anwer Khan Mod Med Col J. 2011; 2(2):18-20.

7. Sharma BR, Harish D, Singh VP, Bangar S. Septicemia as a cause of death in burns: an autopsy study. Burns 2006;32:5459.

8. Sagar MS, Sharma RK, Dogra TD. Analysis of changing patterns of unnatural fatalities in south Delhi (comparative study of 1977-80 \& 1988-91). J For Med Toxicol 1993;10(1):21-5.

9. Vipul NA, Hemant VG. Study of burn deaths in Nagpur, Central India. Burns 2006;32:902-8.

10. Chavan KD. Study of suicidal deaths in rural beed districts of Maharashtra. Int J Med Toxicol Legal Med 1999;1:29-31.

11. Gupta RK and Srivastava AK. Study of Fatal burn cases in Kanpur (India). Forensic Sci Int 1988;37(2):81-9.

12. Rao N, Kumar G. Study of fatal female burns in Manipal. J For Med Toxicol 1997;9(4):57-9.

13. Memchoubi P, Nabachandra H. A study of burns in Imphal. $J$ Indian Acad Forensic Med 2007;29(4):3-6.

14. Afify MM, Mahmoud NF, Azzim GH Abd El, Desouky NA El. Fatal burn injuries: A five year retrospective autopsystudy in Cairo city, Egypt. Egypt J Forensic Sci J 2012;2:11722.

15. Reig A, Tejerina C, Baena P, Mirabet V. Massive burns: a study of epidemiology and mortality. Burns 1994;20:51-4.

16. Park JG. Epidemiology of fatal burn injuries. J For Sci 1989;34(2):399-406. 
17. Buchade D, Mohite, S. Trends in culpable ho micide amounting to murder in the city of Greater Mumbai: A fiveyear study. Medico-Legal Update 2010;10:12-4.

18. Mohanty MK, Mohanty S, Acharya S. Circumstances of crime in homicidal deaths. Medicine, Science and the Law 2004; 44:160-4.

19. Mandong BB, Manasseh AN, Ugwu BT. Medicolegal autopsies in North Central Nigeria. East Afr Med J 2006; 83:626-30.

20. Khan BH, Hossain MM. Study on unnatural death patterns in Dhaka City. Anwer Khan Mod Med Col J. 2011; 2(2):18-20.

21. Sharma G, Shrestha PK, Wasti H, Kandel T, Ghimire P, Dhungana S. A review of violent and traumatic deaths in Kathmandu, Nepal. Int J Inj Contr Saf Promot 2006; 13(3):197-9.

22. Prasad BK, Prasad C. Road traffic accident (RTA) as major killer: A report on medico-legal autopsies in Bharatpur hospital. Kathmandu Univ Med J (KUMJ) 2003; 1(1):34-5.

23. Subedi N, Yadav BN, Jha S, Paudel IS, Regmi R. A profile of abdominal and pelvic injuries in medico-legal autopsy. $J$ Forensic Leg Med. 2013;20(6):792-6.

24. Husaini N, Chavan KD, Bangal RS, Singh B. Pattern of thoraco-abdominal injuries in rural region. Indian J Forensic Med Pathol. 2009;2:97-103

25. Wong ZH, Chong CK, Tai BC, Lau G. A review of fatal road traffic accidents in Singapore from 2000 to 2004. Ann Acad Med Singapore. 2009;38:594-6.

26. Jha N, Srinivasa DK, Roy G, Jagdish S. Epidemiological study of road traffic accident cases: a study from South India. Indian J Community Med 2004;24:20-4.

27. Massie DC, Campbell KL, Williams AF. Traffic accident involvement rates by drivers age and gender. Accid Anal Prev 1995; 27(1):73-87.

28. Rivara, FP, Barber M. Demographic analysis of childhood pedestrian injuries. Pediatrics 1985;76(3):375-81.

29. Shetty SKB, Kanchan T, Menezes RG, Bakkannavar SM, Nayak VC, Yoganarasimha K. Victim Profile and Pattern of ThoracoAbdominal injuries Sustained in Fatal Road Traffic Accidents. JAIFM 2012;34(1):17-20.

30. Jain A, Menezes RG, Kanchan T, Gagan S, Jain R. Two wheeler accidents on Indian roads- A study from Mangalore, India. J Forensic Leg Med 2009;16:130-3.

31. Sharma BR et al. Road Traffic Accidents- A Demographic and Topographic Analysis. Medicine, Science and Law 2001; 41(3):266-74.

32. Singh D, Dewan I, Pandey AN, Tyagi S. Spectrum of unnatural fatalities in the Chandigarh zone of north-west India - A 25 year autopsy study from a tertiary care hospital. J Clin Forensic Med. 2003;10(3):145-52.

33. Kumar TS, Kanchan T, Yoganarasimha K, Kumar GP. Profile of unnatural deaths in Manipal, Southern India 1994-2004. J Clin Forensic Med 2006;13(3):117-20.

34. Menezes RG, Shetty BS, Rastogi P, Padubidri JR, Babu YP, Nagesh KR, D'Souza DH, Shetty M, Monteiro FN, Dsouza HL. The Mangalore Aircrash of 22 May 2010: Practical problems related to identification of the dead in a populous developing country. Med Leg J 2012;80:151-4.

35. Guntheti BK, khaja S, Panda SS. A study of Serum Cholinesterase Levels in Organo phosphorous Poisoning Cases. J Indian Acad Forensic Med 2010;32(4):332-5.

36. Dash SK. Sociodemographic profile of poisoning cases. $J$ Indian Acad Forensic Med 2005;27(3):133-7.

37. Palimar V, Arun M, Saralaya KM, Singh B. Spectrum of Organophoshorous Poisoning in Manipal. Medico-Legal Update 2005;5(2):55-7.

38. Maharani B, Vijayakumari N. Profile of poisoning cases in a Tertiary care Hospital, Tamil Nadu, India. J Appl Pharm Sci 2013;3(1):91-4.
39. Sinha US, Kapoor AK, Agnihotri AK and Srivastava PC. A profile of poisoning cases admitted in SRN Hospital, Allahbad with special reference to Aluminium Phosphide poisoning. $J$ Forensic Med Toxicol 1999;16:40-3.

40. Pokhrel D, Sirjanapant, Pradhan A, Mansoor. A Comparative retrospective study of poisoning cases in central, zonal and district hospitals. Kathmandu Univ J Sci, Eng technol 2008;1: 40-8.

41. Khan NA, Rahman A, Sumon SM, Haque MF, Hasan I, Sutradhar SR, et al. Pattern of Poisoning in a Tertiary Level Hospital. Mymensingh Med J 2013;22(2):241-7.

42. Hettiarachchi J, Kodithuwakku GC. Pattern of poisoning in rural Sri Lanka. Int J Epidemiol 1989;18(2):418-22.

43. Mohanty MK, Kumar V, Bastia BK and Arun M. An Analysis of poisoning deaths in Manipal, India. Vet Hum Toxicol 2004; 46:208-9.

44. Taruni NG, Bijoy T, Momonchand A. A profile of poisoning cases admitted in RIMS Hospital, Imphal. J Forensic Med Toxicol 2001;18:31-2.

45. Gulati RS. Spectrum of acute poisoning cases admitted to service hospital. J Assoc Physic India 1995;43:908.

46. Limaye MR. Acute organophosphorous compound poisoning: a study of 76 necropsies. J Indian Med Assoc 1965;47:492-8.

47. Rao PP, Murty AK, Babu MM, Narayana RV, Devi MU. Clinical profile of 100 cases of poisoning admitted in acute medical care unit. JAPI 1992; 40:206 -10.

48. Senanayake N, Peris H. Mortality due to poisoning in a developing agricultural country: trends over 20 years. Hum Exp Toxicol 1995;12:435-8.

49. Elif D, Akgur SA, Ozturk P, Sen F. Fatal poisoning in Aegean region of Turkey. Vet Hum Toxicol 2003;45:106-8.

50. Paulozzi LJ, Ballesteros MF, Stevens JA. Recent trends in mortality from unintentional injury in the United States. $J$ Safety Res 2006;37(3):277-83.

51. Ahmad M, Hossain MZ. Hanging as a Method of Suicide: Retrospective Analysis of Postmortem Cases. JAFMC Bangladesh 2010;6(2):37-9.

52. David G, Olive B, Keith H, Sue S, Nav K. The epidemiology and prevention of suicide by hanging: A systematic review. Int J. Epidemiol 2005;34(2):433-42.

53. Cooke CT, Cadden GA, Margolius KA. Death by hanging in western Austrialia. Pathology 1995;27(3):268-72.

54. Memchoubi P, Nabachandra H. A study of burn deaths in Imphal. J Indian Acad Forensic Med 2007;29(4):131-4.

55. Adamo C, Esposito G, Lissia M, Vonella M, Zagaria N, ScuderiN. Epidemiological data on burn injuries in Angola: A retrospec-tive study of 7230 patients. Burns 1995;21:536-8.

56. Virendra K, Manoj KM, Sarita K. Fatal burns in Manipal area: A 10 year study. J Forensic Leg Med 2007;14:3-6.

57. Gupta M, Gupta OK, Yaduvanshi RK, Upadhyaya J. Burn epidemiology: the Pink City scene. Burns 1993;19(1):47-51.

58. El Danaf. Burn variables influencing survival: a study of 144 patients. Burns 1995;21:517-20.

59. Vilasco, Bondurand A. Burns in Abidjan Cote D'Ivoire. Burns 1995;21:291-6.

60. Barret JP, Gomez P, Solano I, Dorrego MG, Crisol FJ. Epidemiology and mortality of adult burns in Catalonia. Burns 1999;25:325-9.

61. Bloemsma GC, Dokter J, Boxma H, Oen IM. Mortality and causes of death in a burn centre. Burns 2008; 34:1103-7.

62. Khadim MF, Rashid A, Fogarty B, Khan K. Mortality estimates in the elderly burn patients: The Northern Ireland experience. Burns 2009; 35:107-13.

63. Rao K, Ali SN, Moiemen NS. Aetiology and outcome of burns in the elderly. Burns 2006; 32:802-5.

64. Mann JJ. A current perspective on suicide and attempted suicide. Ann Intern Med 2002; 136:302-11. 
65. Hirschfeld RM, Russell JM. Assessment and treatment of suicidal patients. $N$ Engl J Med 1997; 337:910-15.

66. Hawton K, Saunders KE, O'Connor RC. Self-harm and suicide in adolescents. Lancet 2012; 379(9834):2373-82.

67. Chang B, Gitlin D, Patel R. The depressed patient and suicidal patient in the emergency department: Evidence-based management and treatment strategies. Emergency medicine practice 2011;3(9):1-23.

68. Simpson G, Tate R. Suicidality in people surviving a traumatic brain injury: Prevalence, risk factors and implications for clinical management. Brain Injury 2007; 21(13-14):1335-51.

69. Chehil, Kutcher S, Sonia. Suicide Risk Management A Manual for Health Professionals. $2^{\text {nd }}$ ed. Chicester: John Wiley \& Sons; 2012.

70. Bertolote JM, Fleischmann A, Leo DD; Wasserman D. Psychiatric diagnoses and suicide: Revisiting the evidence. Crisis. 2004;25(4): 147-55.

71. Van Os J, Kapur S. Schizophrenia. Lancet 2009; 374(9690):635-45.

72. Shneidman, ES. Suicide As Psychache: A Clinical Approach To Self-Destructive Behavior. Northvale, NJ/London: Jason Aronson, Inc; 1993.

73. Zanzrukiya K, Tailor C, Chandegara P, Govekar G, Patel U, Parkhe S. Profile of homicidal death cases at Government Medical College \& new civil hospital, Surat. Int J Medical Sci Public Health 2014;3(7):885-8.

74. Prajapati P, Sheikh MI, Patel S. A study of homicidal deaths by mechanical injuries in Surat, Gujarat. J Indian Acad Forensic Med 2010;32:134-8.

75. Hugar BS, Girish Chandra YP, Harish S. Victim Profile in Homicides. Indain J Forensic Med Toxicol 2011;5(1):16-9.

76. Vij A, Menon A, Menezes RG, Kanchan T, Rastogi P. A retrospective review of homicides in Mangalore, South, India. J Forensic Leg Med 2010;17(6):312-5.

77. Padmaraj RY, Tandon RN. Pattern of homicides at mortuary of civic hospital Ahmedabad. J Forensic Med Toxicol 2010;27:51-5.

78. Avis SP. Homicide in Newfoundland: a nine-year review. $J$ Forensic Sci 1006;41:101-5.

79. Hunt AC, Cowling RJ. Murder by stabbing. For Sci Int 1991;52:107-12
80. Kumar V, Mae LAK, Zanial AZ, Lee DA, Salleh SA. A study of Homicidal deaths in medicolegal autopsies at UMMC, Kuala Lumpur. J Clin Forensic Med 2005;12:254-7.

81. Lee GM, MacNeill S, Rizet D, McDermott SD.

Homicide/suspicious death statistics for cases submitted to the forensic science laboratory in the Republic of Ireland for 20042008. Medicine, Science and the Law 2011;51:146-50.

82. Patel DJ. Analysis of homicidal deaths in and around Bastar region of Chhattisgarh. J Indian Acad Forensic Med 2012;34(2):139-42.

83. Dikshit PC, Kumar A. Study of Homicidal Deaths in central Delhi. JFMT; 20(1): 47-51.

84. Kominato Y, Shimada I, Hata N, Takiwaza H. Homicide patterns in the Toyama Prefecture, Japan. Med. Sci. Law 1897;37(4):316-20.

85. Forest De, Ganesslen ER, Lee CH. Tool marks and firearm. In: Forensic Sciences: An Introduction to criminalistics. $1^{\text {st }}$ edition, New York: McGraw Hill; 1983.

86. Mian AR, Majid A, Malik MM, Zaheer M, Goraya SU. Analysis of unnatural Death in Rawalpindi during 1997. Pak Armed Forces Med J 1999;49(1):68-70.

87. Aziz K, Rana P. Malik SA. Homicide in Lahore Pakistan. Postgrad Medical J 1999;10(1):10-13.

88. Ali SMA, Rizvi SIH, Ali MA, Chaudhry TH. Weaponry Patterns in the homicidal deaths in Bahawalpur. The Professional 2000;7(4):514-6.

89. Qadir G, Aziz K. The study of Homicidal deaths in Larkana. Postgrad Medical J 2000;11(2):79-80.

90. Eze UO, Akang EEU, Odesanmi WO. Pattern of homicide coroner's autopsies at university college hospital, Ibadan, Nigeria: 1997-2006. Med Sci Law 2011;51:43-8.

91. Hilal, A, Cekin N, Gülmen MK, Ozdemir MH, Karanfil R. Homicide in Adana, Turkey: A 5-year review. Am J Forensic Med Pathol 2005;26:141-5.

How to cite this article: Deepak M, Shetty B, Monteiro F N.P, Castelino KP, Xavier AP, Shetty T, Spectrum of unnatural deaths: autopsies conducted at A. J. Institute of medical sciences \& research centre, mangalore. Int $J$ Forensic Med Toxicol Sci 2019;4(4):111-7. 